\title{
Florida Fresh: Cantaloupes ${ }^{1}$
}

\author{
Claudia Peñuela ${ }^{2}$
}

Nutrition Facts

Florida's Cantaloupes are:

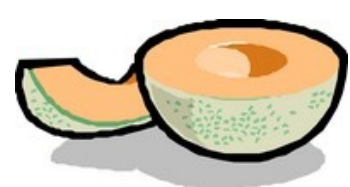

$\checkmark$ High in vitamin A. Vitamin A aids in maintaining normal vision and healthy skin, and protects against infections.

$\checkmark$ High in vitamin C. Vitamin C helps to heal cuts

and keeps teeth and gums healthy.

$\checkmark$ A good source of potassium. Potassium helps control blood pressure. $\checkmark$ Naturally free of cholesterol and low in sodium.

Note: Cantaloupes are a variety of melons. There are other varieties of melons such as casaba and honeydew melons that are not included in this fact sheet.

\section{Why Buy Locally?}

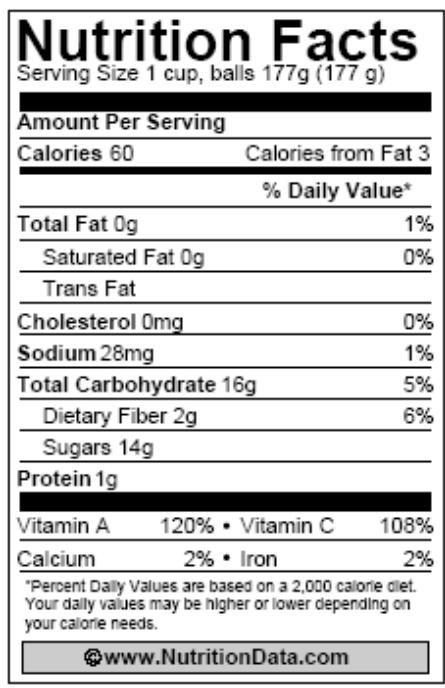

The U.S. Department of Agriculture (USDA) estimates that the average farmers' market produce travels about $\mathbf{5 0}$ miles to its destination, compared to $\mathbf{2 , 0 0 0}$ miles for supermarket produce.

Buy locally and get these benefits:

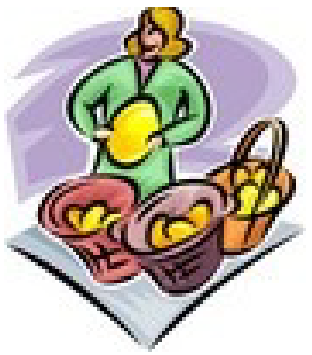

$>$ Freshness and good nutrition. Fruits and vegetables harvested in their peak have better flavor and nutritional characteristics.

$>$ Social/cultural. Helps the community to be aware of the importance of agriculture.

$>$ Environmental. Protects the natural resources such as green space, wildlife, water, air, and soil.

$>$ Economic. Promotes local labor force.

\section{Where are Florida's cantaloupes harvested?}

Florida's cantaloupes are harvested throughout the state, but the majority of the crops are in Central Florida. Florida is an important producer thanks to the warm sunshine and frost-free seasons.

1. This document is FCS8878, on e of a series of the Department of Family, Y outh and Community Sciences, Florida Cooperative Extension Service, Institute of Food and Agricultural Sciences, University of Florida. First published: August 2009. Visit the EDIS Web site at http://edis.ifas.ufl.edu.

2. Claudia P eñuela, nutrition a ssistant-EFNEP, D epartment of F amily, Y outh and Community S ciences; Institute of Food and A gricultural S ciences; University of Florida; Gainesville, FL 32611.

The Institute of Food and Agricultural Sciences (IFAS) is an Equal Opportunity Institution authorized to provide research, educational information and other services only to individuals and institutions that function with non-discrimination with respect to race, creed, color, religion, age, disability, sex, sexual orientation, marital status, national origin, political opinions or affiliations. U.S. Department of Agriculture, Cooperative Extension Service, University of Florida, IFAS, Florida A. \& M. University Cooperative Extension Program, and Boards of County Commissioners Cooperating. Millie Ferrer-Chancy, Interim Dean. 


\section{When can you buy Florida cantaloupes?}

You can buy Florida cantaloupes from March through July. This is five months out of the year!

\begin{tabular}{|l|l|l|l|l|l|l|l|l|l|l|l|}
\hline JAN & FEB & MAR & APR & MAY & JUN & JUL & AUG & SEP & OCT & NOV & DEC \\
\hline
\end{tabular}

\section{Select}

$\checkmark$ Sweet-smelling cantaloupes with a soft stem end, and a creamy yellow-colored rind. These are ripe and at their peak flavor.

$\checkmark$ Symmetrical, well-shaped cantaloupes.

$\checkmark$ Cantaloupes that are heavy for their size.

$\checkmark$ Cantaloupes without bruises, soft spots, and cracked rinds.

Consider these tips: Wash any kind of melons before cutting. Cut melons have to be refrigerated in sealed containers.

\section{Florida Fresh Cantaloupes: From Market to Table}

\section{Fruit Slush}

$2 \frac{2}{3}$ cups coarsely chopped cantaloupe, seeded and peeled

$12 / 3$ cups coarsely chopped kiwi (optional)

2-3 Tbsp sugar

2 Tbsp lime juice

2 cups water

ice

\section{Melon Salsa}

2 cups seeded and chopped cantaloupe 1 cup peeled, seeded and chopped cucumber $1 / 4$ cup chopped onion, red or white

2 Tbsp chopped cilantro or mint (optional)

$1 / 2$ single, seeded, and finely chopped jalapeño or hot sauce to taste

$1 / 4$ cup lime juice or lemon juice

1 Tbsp sugar, white or brown

\section{Yield: 4 Servings}

1. In a blender, purée fruit with sugar and lime juice until smooth.

2. Combine fruit mixture and water in a large pitcher.

3. If preferred, pour through a strainer to eliminate pulp.

4. Cover and refrigerate for up to a week.

5. Serve well-mixed in tall glasses with ice (garnish with mint if desired).

*Nutrition info per serving ( $1 / 4$ of recipe) 239g: Calories: 60 cal; Total Fat 0g; Sodium 20mg; Total Carbohydrate 16g; Fiber 1g; Protein 1g; Vit A 70\%; Vit C 70\%; Calcium 2\%; Iron 2\% *Vitamin A, Vitamin C, Calcium and Iron listed as $\%$ of daily value based on 2,000 calories.

Adapted from: Pictorial Recipes, Lynn Myers Steele, 2000, Oregon Family Nutrition Program, Oregon State University Extension Service; and http://recipefinder.nal.usda.gov/index.php?mode=display\&rec id=57

\section{Yield: 12 Servings}

1. In an appropriate size bowl, stir together all ingredients.

2. Taste and add more lemon or lime juice, sugar if needed.

3. Cover and refrigerate for at least $\mathbf{3 0}$ minutes. Serve with grilled or broiled fish or chicken.

Caution: Hot pepper contains oils that can cause burning and skin irritation. You should wear kitchen gloves or wash your hands immediately after touching them. Do not touch your eyes.

Nutrition info per serving size (45g): Calories $15 \mathrm{cal}$; Total Fat 0g; Sodium 0mg; Total Carbohydrate 4g; Protein 0g.

Adapted from: Montana Extension Nutrition Education Program, Website Recipes, Montana State University Extension Service; and http://recipefinder.nal.usda.gov/index.php?mode=display\&rec id=486 